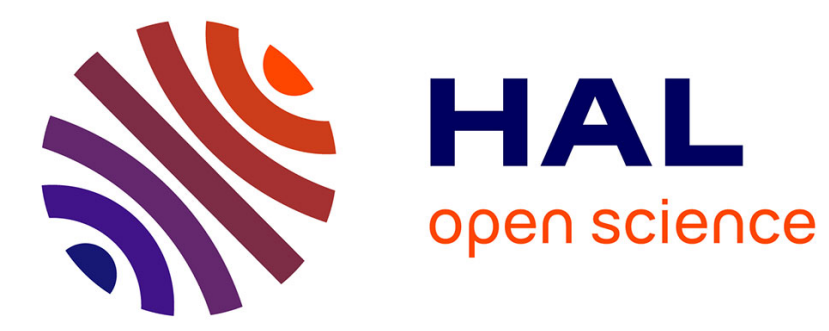

\title{
Seedling recruitment in mountain grassland restoration: Effects of soil preparation and grazing
}

Aure Durbecq, Margaux d'Ambly, Elise Buisson, Renaud Jaunatre, Alexandre Cluchier, Armin Bischoff

\section{- To cite this version:}

Aure Durbecq, Margaux d'Ambly, Elise Buisson, Renaud Jaunatre, Alexandre Cluchier, et al.. Seedling recruitment in mountain grassland restoration: Effects of soil preparation and grazing. Applied Vegetation Science, 2021, 24 (1), pp.e12564. 10.1111/avsc.12564 . hal-03174057

\section{HAL Id: hal-03174057 https://hal.science/hal-03174057}

Submitted on 26 Jan 2022

HAL is a multi-disciplinary open access archive for the deposit and dissemination of scientific research documents, whether they are published or not. The documents may come from teaching and research institutions in France or abroad, or from public or private research centers.
L'archive ouverte pluridisciplinaire HAL, est destinée au dépôt et à la diffusion de documents scientifiques de niveau recherche, publiés ou non, émanant des établissements d'enseignement et de recherche français ou étrangers, des laboratoires publics ou privés. 
1 Seedling recruitment in mountain grassland restoration: effects of soil preparation and grazing

2 *Aure Durbecq $^{1,2}$, Margaux d’Ambly ${ }^{1}$, Elise Buisson ${ }^{1}$, Renaud Jaunatre ${ }^{3}$, Alexandre Cluchier ${ }^{2}$, $3 \quad$ Armin Bischoff ${ }^{1}$

4

$5 \quad{ }^{1}$ Mediterranean Institute of Biodiversity and Ecology (IMBE), Avignon University, CNRS, IRD, Aix

6 Marseille University, Avignon, FR

$7 \quad 2$ Ecology consultancy ECO-MED, Marseille, FR

$8{ }^{3}$ Univ. Grenoble Alpes, INRAE, LESSEM, F-38402 St-Martin-d'Hères, France

9

10

11

Correspondence: Aure Durbecq, IMBE, Avignon University, CNRS, IRD, Aix Marseille University,

12 IUT, Avignon, FR.

13 Email: aure.durbecq@gmail.com

14

15

16

17

18

Funding information

19

Financial support was provided by RTE (Electricity Transmission Network), the ecology

20

consultancy ECO-MED and ANRT (National Agency of Research and Technology) via a grant

21

CIFRE N² 2017 / 0478.

22

Abstract 
1 Questions: Seedling recruitment is a key step in any seed-based ecological restoration project.

2 There is a controversial discussion i) whether soil preparation is required to reduce competition

3 of pre-existing vegetation, or whether vegetation cover facilitate seedling recruitment, and ii)

4 whether grazing should be excluded in initial stages of grassland restoration to protect

5 seedlings, because grazing exclusion may also favour competitive ruderal species. We set up a combined soil preparation and grazing experiment to evaluate the effect of both factors on

7 seedling recruitment of seeds transferred from a species-rich donor site.

Location: Upper Durance valley, Hautes-Alpes, France.

9 Methods: The experiment was set up using a full factorial split-plot design with five replicate sites. The treatments included soil preparation (harrowed or not) and grazing (excluded or not). Seeds were transferred using plant material brushed in a non-degraded reference grassland. The individuals of all occurring species were counted on the restoration sites, and the survival and reproduction of two focal species, Bromopsis erecta and Rhinanthus alectorolophus, were recorded for three months.

Results: Soil preparation by harrowing reduced the density of spontaneously emerging species and increased the seedling density of species transferred from the donor site. Grazing had only a weak negative effect on the recruitment of transferred species. The main effect of both treatments on seedling survival was not significant, but a significant interaction indicated that the grazing effect depended on soil preparation, with a negative effect of grazing only in nonharrowed plots.

21 Conclusions: The reduction of competition by soil preparation before seed addition of brush material had a positive effect on the seedling recruitment of transferred species and can thus 
1 clearly be recommended in our study system. The weak negative effect of grazing may not

2 always justify fencing costs.

3

4

5

6 KEYWORDS

7 Bromopsis erecta, brush harvesting, community ecology, ecological engineering, grassland

8 restoration, grazing, harrowing, montane grasslands, Rhinanthus alectorolophus, seedbed

9 preparation, seedling establishment, survival.

10

11

12

13

14

15

16

17

18

19

20

21

22

23

24 
2 Seedling recruitment is an important process driving the composition and diversity of plant

3 communities (Grubb, 1977; Zeiter et al., 2006). Understanding the factors constraining seedling

4 recruitment is thus crucial to predict and improve restoration success. Dispersal (Münzbergová

5 and Herben, 2005; Frances et al., 2010) and microsite limitation (Myers and Harms, 2009; Long et al., 2014) are known to be such constraining factors in re-colonisation processes. In grassland restoration, the small soil seed bank of typical late-successional species may result in insufficient seedling recruitment (Grman et al., 2015; Buisson et al., 2018). Poor seed dispersal, as well as the lack of connectivity between source populations due to landscape fragmentation, often limit the seed rain (Münzbergová and Herben, 2005; Bischoff et al., 2009; Muller et al., 2014) and successful restoration may require seed addition to overcome seed limitation (Öster et al., 2009; Török et al., 2012; Valkó et al., 2016). Thus, seed addition methods such as sowing local seed mixtures, hay transfer or soil transfer, are increasingly used in grassland restoration (Kiehl et al., 2010; Scotton et al., 2012; Kiss et al., 2020). constraint influencing plant establishment (Tilman, 1997; Turnbull et al., 2000; Pywell et al., 2002). Unfavourable microsite conditions may hamper germination and reduce seedling survival often resulting in microsite limitation (Bissels, 2006). Soil disturbance, such as topsoil removal or soil tillage, increases recruitment opportunities (Hölzel and Otte, 2003; Myers and Harms, 2009; Long et al., 2014; Klaus et al., 2017). Soil preparation (also called "seedbed preparation"; Shaw et al., 2020) may promote the recruitment of plant species by (i) limiting the competition of an already established vegetation, and by (ii) improving abiotic conditions 
1 facilitating effect on recruitment by protecting seedlings from high solar radiation and drought

2 stress (Callaway and Walker, 1997). However, if pre-existing vegetation is dense, the

3 competitive effect on introduced species may prevail because already established species limit

4 available space and resources (Kupferschmid et al., 2000; Poschlod and Biewer, 2005).

5 Preparing the soil may favour seedling recruitment of new species by opening the vegetation

6 and destroying the root systems of competitive perennial species (Bischoff et al., 2018). Soil

7 preparation further creates micro-reliefs improving seed and water retention as well as seed

8 adhesion (Chambers, 2000). However, soil disturbance increases nitrogen mineralisation

9 increasing plant available nitrogen in the soil (eutrophication) and may negatively affect the soil

fauna and soil structure potentially favouring erosion (Di and Cameron 2002; Holland 2004).

Human land management by grazing and mowing is a key factor regulating the functioning and structure of semi-natural grasslands (Hejcman et al., 2013). Several studies confirmed the essential role of grazing in maintaining plant species richness of grassland ecosystems (Dupré and Diekmann, 2001; Pykälä, 2003, Saatkamp et al., 2018). However, in the initial stages of grassland restoration, grazing may hamper seedling recruitment since seedlings are particularly vulnerable to trampling and biomass removal by herbivory (Bakker, 2003; Buisson et al., 2015). Trampling may prevent species from germinating by crushing and damaging seeds or coleoptiles (Rother et al., 2013). Moreover, trampling on slopes may lead to soil destabilization (Tasser et al., 2003), increases soil erosion (Farrell and Fehmi, 2018) and soil compaction (Allington and Valone, 2011). However, in mountain ecosystems, in which the particular pedo-climatic conditions (soil erosion, shallow and stony soils) reduce seedling recruitment, micro-reliefs created by hoof prints may increase seed trapping (Isselin-Nondedeu et al., 2006) and improve seed adhesion to the soil (Chambers, 2000). Accordingly, Eichberg and Donath (2018) found an increased seedling recruitment in a trampling simulation 
1 experiment on sandy soils also suffering from low stability and high run-off. Biomass removal

2 by herbivory damages seedlings and often reduces initial seedling survival (Buisson et al., 2015;

3 Vidaller et al., 2019b). However, Farrell and Fehmi (2018) only found a combined negative

4 effect of trampling and herbivory whereas herbivory alone did not affect seedling

5 establishment. Furthermore, Kladivová and Münzbergová (2016) even revealed a positive

6 effect of grazing on both seedling recruitment and establishment but the grazing effect

7 depended on habitat conditions at the specific microsite.

8

9

In our study, we aim to test the effect of soil preparation and grazing on seedling recruitment (combining germination and early survival) in a seed-addition experiment conducted in semi-natural mountain grasslands. Using brush material transferred from a species-rich donor grassland to restore degraded sites, we addressed the following questions: (1) Does soil preparation by harrowing before sowing improve seedling recruitment and survival of the transferred species? (2) What is the effect of early grazing on seedling recruitment and survival of the transferred species?

\section{MATERIALS AND METHODS}

\section{Study area}

The study area is the upper Durance valley ("Haute-Durance") in the Southern French Alps. The construction of a high-voltage transmission line led to a local destruction of species-rich grassland communities within a 1 km wide and 100 km long strip from L'Argentière-la-Bessée to La-Batie-Neuve $\left(44^{\circ} 78^{\prime} 78^{\prime \prime} \mathrm{N}, 6^{\circ} 59^{\prime \prime} 41^{\prime} \mathrm{E} ; 44^{\circ} 57^{\prime} 93^{\prime \prime} \mathrm{N}, 6^{\circ} 20^{\prime \prime} 77^{\prime} \mathrm{E}\right)$. The experimental sites representing a subsample of these grasslands are located between 1100 and 1300 meters above the sea level (upper montane altitudinal belt). The climate is temperate to sub- 
1 Mediterranean depending on slope, exposition and elevation. At the closest meteorological

2 station (Embrun), the annual precipitation is about $740 \mathrm{~mm}$ and the mean annual temperature

$310.7^{\circ} \mathrm{C}$. Considering the lower elevation of the station $(880 \mathrm{~m})$ the temperature is roughly $2^{\circ} \mathrm{C}$

4 lower resulting in an annual mean of $8.7^{\circ} \mathrm{C}$ at our experimental sites. The bedrock is

5 predominantly calcareous with some quaternary glacial deposits. Non-degraded grasslands of

6 the study area belong to Natura 2000 priority habitats: "Semi-natural dry grasslands of Festuco-

7 Brometalia and scrubland facies on calcareous substrates" (N6210*, EU directive habitat

8 92/43/EEC; Calaciura and Spinelli, 2008) that are traditionally managed either by mowing,

9 cattle and sheep grazing. On transitory access tracks and construction platforms, the vegetation was removed, and the soil compacted to facilitate the transport of heavy equipment. To recreate former soil conditions after electricity line construction the soil was de-compacted by deep tillage between May and July 2018.

\section{Donor site and seed harvest}

The donor site to collect brush material is located within the study area at Freissinières at an elevation of $1100 \mathrm{~m}\left(44^{\circ} 73^{\prime} 61^{\prime \prime} \mathrm{N} ; 6^{\circ} 56^{\prime} 72^{\prime \prime} \mathrm{E}\right)$. The soil and climatic conditions of the donor site corresponded to the average of the five experimental sites. The seed material was harvested in July 2018 using a brush harvester mounted on a quad and equipped with an integrated vacuum system. On a surface of $4000 \mathrm{~m}^{2}$, we obtained $2.6 \mathrm{~kg}$ of brush material. The brush material comprised seeds (60\% of total mass) and vegetative parts (40\%). Seed counts in ten subsamples of $0.5 \mathrm{~g}$ revealed an average density of 887 seeds/g of brush material. A single harvest was considered as sufficient since the short summer season in the study area has resulted in a concentration of the seed production period for most species. 


\section{Experimental set-up and design}

2 The experiment was set up in October 2018 using a full factorial split-plot design replicated on

3 five sites (blocks) to test the effect of previous soil preparation, grazing and its interaction on

4 seedling recruitment (see Durbecq et al., 2020, for the position of experimental sites). Each of

5 the five sites comprised eight plots of $16 \mathrm{~m}^{2}$ each $(4 \mathrm{~m} \times 4 \mathrm{~m})$ resulting in a total of 40 plots.

6 Four plots representing a half-block were exposed to extensive grazing and the remaining four

7 were fenced preventing grazing (whole-plot factor). The sowing and soil preparation treatments (split-plot factors) were randomly assigned within half-blocks. The distance between plots was $1 \mathrm{~m}$ except for the Embrun site where this distance was reduced to $50 \mathrm{~cm}$ due to limited space.

The full design also comprised unsown control plots randomly assigned to half-blocks.

The unsown plots were used to evaluate which plant species of the donor grassland already occurred at the restoration sites before the brush material was transferred (soil seed bank, seed rain). Average vegetation cover of these unsown controls was $28 \%$ compared with $90 \%$ at the donor site. Species occurring in the control plots of a given site were considered as "spontaneously emerging" for this site. Only plant species of the donor site not occurring in the control plots were considered as "transferred" (Appendix S1). The method may underestimate the density of transferred species since species occurring in unsown control plots may still have been transferred to the sown plots.

Sites already covered with spontaneous vegetation were mown prior to experimental set-up. Harrowing was selected as a soil preparation method using a rotary harrow adjusted to a working depth of $8 \mathrm{~cm}$. In October 2018, just after harrowing, the brushed material was spread at a density of $104 \mathrm{~g} /$ plot corresponding to a seed density of $3.75 \mathrm{~g} / \mathrm{m}^{2}$ and approximatively 5765 seeds $/ \mathrm{m}^{2}$. The chosen seed density was based on recommendations of 
1 a previous research project in the French Alps (Koch et al., 2015). In agreement with the

2 traditional local grazing regime, the unfenced experimental plots were grazed twice a year: in

3 late October just after experimental set up, and in early June. Two sites were grazed by cattle,

4 three sites by sheep, corresponding to the average proportion of both grazing types in the study

5 region. The sites were neither fertilised nor irrigated.

\section{Data collection}

8 Vegetation relevés at the donor site and germination tests in the greenhouse

9 Prior to seed harvest, the cover of all occurring vascular plant species was estimated in five representative $3 \mathrm{~m} \times 3 \mathrm{~m}$ plots as the vertical projection cover of above-ground vegetation in late June 2018. We used Tison et al. (2014) for plant species identification and as reference for plant species names. At the harvest in July 2018, the average phenological stage of all species was recorded in order to evaluate seed availability. Eighty percent of the species recorded in June were found to have seeds in July.

In order to obtain information on the germination potential of seeds contained in the brush material and to evaluate germination in the field compared with germination potential, we set up a germination test in November 2018. Subsamples of the brush material were transferred to five trays $\left(0.03 \mathrm{~m}^{2}\right)$ filled with standard peat substrate and placed in an unheated greenhouse. Each tray received $0.54 \mathrm{~g}$ of brush material corresponding to $18 \mathrm{~g} / \mathrm{m}^{2}$ and a density of approximately 18000 seeds per $\mathrm{m}^{2}$. The trays were regularly watered, and germination was recorded until April 2019. Greenhouse germination of the harvested brush material was recorded once a week for four months and seedlings were removed after identification. 
1 To quantify seedling recruitment of both transferred species and spontaneously emerging species, plant numbers were counted in three quadrats of $40 \mathrm{~cm} \times 40 \mathrm{~cm}$ placed along the diagonal of each plot. Since we were not able to distinguish seedlings and plants re-sprouting

4 from below-ground organs, the seedling counts may include young ramets of clonally growing 5 plants. In order to identify spontaneously emerging species, we conducted at the same time vegetation relevés on the unsown control plots $\left(9 \mathrm{~m}^{2}\right)$.

Seedling survival of focal species

8 Seedlings of two typical species of the donor site, Bromopsis erecta (Huds.) Fourr. (former 9 name: Bromus erectus) and Rhinanthus alectorolophus (Scop.) Pollich were monitored over 11 weeks in order to assess seedling survival. B. erecta is the characteristic species of semi-dry grasslands (Mesobromion type sensu Ellenberg, 1996) occupying a large range in Europe. It is further one of the typical species of the habitat type (N6210*, EU directive habitat 92/43/EEC; Calaciura and Spinelli, 2008). B. erecta is a perennial grass growing on calcareous and often nutrient-poor soils. R. alectorolophus is a summer annual, hemi-parasitic species growing in semi-dry to mesophilic calcareous grasslands. As B. erecta, it is among the characteristic species of the N6210*-habitat type. $R$. alectorolophus has a wide range of hosts that includes grasses and legumes (Sandner and Matthies, 2018). The species is used as a tool in restoration of species-rich grasslands as it reduces competition by grasses and may thus have a positive effect on plant diversity (Bullock and Pywell, 2005; Heer et al., 2018). In all sown plots (four plots per site), ten randomly chosen seedlings of both species were tagged in May 2019 using coloured rings and poles (Appendix S2). A total of 400 seedlings were tagged over the five sites. The position of each individual was mapped, and each seedling was numbered in order to facilitate localization and recognition. Seedling survival and reproduction of these two focal species were recorded in late July 2019. 


\section{Data analysis}

3 We analysed (i) seedling numbers and species richness of the total plant community ("all

4 species" $^{\prime \prime}$ spontaneously emerging species + transferred species), and of transferred species

5 only, as well as (ii) the survival of the two focal species, Bromopsis erecta and Rhinanthus

6

7 alectorolophus.

Generalized linear mixed models were applied to assess the effect of soil preparation (harrowing: yes/no) and of grazing (yes/no) on seedling recruitment and the survival of $B$. erecta and $R$. alectorolophus. The full model included the two factors and the grazing-by-soil preparation interaction as fixed effects and site as a random effect. In order to include the splitplot design of the experiment, a grazing-by-site interaction (random) was fitted to the model to test the whole-plot factor (grazing). Harrowing (split-plot factor) and the site-by-harrowing interaction were tested against the model residuals. Abundance data were right-skewed but models with Poisson error distribution and log-link function showed overdispersion. Thus negative binomial error distribution and log-link function were finally used to test total abundance and abundance of transferred species. Species richness was tested using Gaussian error distribution and identity link. Both models additionally included quadrat within plots as a random factor. Survival was analysed at plot level and did not include quadrat. A binomial error distribution was fitted using a logit-link function.

Non-Metric Multidimensional Scaling (NMDS) based on Bray-Curtis similarity was applied to compare plant species composition in different treatments (Borcard et al., 2011). A permutation multivariate analysis of variance (PERMANOVA, Anderson 2001) with 9999 permutations was used to analyse whether the community composition was significantly 
different between the grazing and soil preparation treatments (R package "vegan", Oksanen et al., 2019). All analyses were performed using R 3.5.3 (R Core Team, 2019).

\section{RESULTS}

\section{Seedling emergence}

A total of 21 plant species germinated in the greenhouse corresponding to $37.5 \%$ of the total species number observed at the donor site. At the restoration sites, 29 donor site species (51.8\%) were found. Taking into account the difference in the amount of seed material used in the greenhouse test and at the restoration sites, the final germination was 40 times higher in the greenhouse (7.31 seeds/g) than in the field (0.17 seeds/g; Appendices S3). In particular, Plantago media L., Festuca marginata (Hack.) K.Richt. and Schedonorus pratensis (Huds.) P.Beauv. showed a much higher greenhouse germination whereas the difference between greenhouse and field was much smaller in B. erecta ( 4 times higher in the greenhouse). $R$. alectorolophus did not germinate in the greenhouse.

\section{Seedling recruitment}

Soil preparation by harrowing reduced overall seedling recruitment including that of spontaneously emerging species. Grazing had a marginally significant negative effect on seedling recruitment (Table 1, Fig. 1a). The opposite effect of harrowing was observed for transferred plant species. Twice as many seedlings of transferred species were found in the harrowed than in the non-harrowed plots (Fig. 1b). Grazing resulted in a 50\% reduction of the seedling density of transferred species, but due to the high between-site variation the grazing effect was only marginally significant . The grazing-by-soil preparation interaction was not significant for both response variables. 
3 Table 1. Effect of harrowing and grazing on number of seedlings per $\mathrm{m}^{2}$, species richness and

4 the survival of two focal species. Results on seedling number and richness are presented

5 separately for the whole plant community and the subsample of transferred species. $\mathrm{H} \times \mathrm{G}=$

6 grazing-by-harrowing interaction. Results of GLMM with Chi-Square ( $\chi 2)$ and significance levels:

$7 . \mathrm{P}<0.1, * \mathrm{P}<0.05, * * \mathrm{P}<0.01, * * * \mathrm{P}<0.001, \mathrm{NS}$ not significant.

\begin{tabular}{llllllll}
\hline & $d f$ & \multicolumn{2}{c}{ Seedling number } & \multicolumn{2}{c}{ Species richness } & \multicolumn{2}{c}{ Survival } \\
& & $\begin{array}{l}\text { All } \\
\text { species }\end{array}$ & $\begin{array}{l}\text { Transferred } \\
\text { species }\end{array}$ & $\begin{array}{l}\text { All } \\
\text { species }\end{array}$ & $\begin{array}{l}\text { Transferred } \\
\text { species }\end{array}$ & $\begin{array}{l}\text { Bromopsis } \\
\text { erecta }\end{array}$ & $\begin{array}{l}\text { Rhinanthus } \\
\text { alectorolophus }\end{array}$ \\
\hline Harrowing & 1 & $7.097^{* *}$ & $6.435^{*}$ & 3.476. & $6.308^{*}$ & $2.484 \mathrm{NS}$ & $0.741 \mathrm{NS}$ \\
Grazing & 1 & 3.726. & 3.440. & $2.661 \mathrm{NS}$ & 2.804. & $1.799 \mathrm{NS}$ & $2.585 \mathrm{NS}$ \\
HxG & 1 & $0.560 \mathrm{NS}$ & $0.011 \mathrm{NS}$ & $0.014 \mathrm{NS}$ & $1.095 \mathrm{NS}$ & $5.089 *$ & $4.851^{*}$ \\
\hline
\end{tabular}

8

9

10

(a)

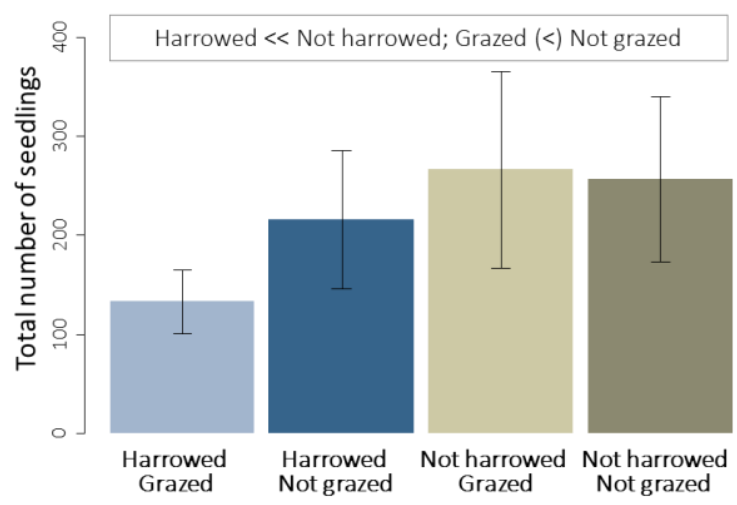

(b)

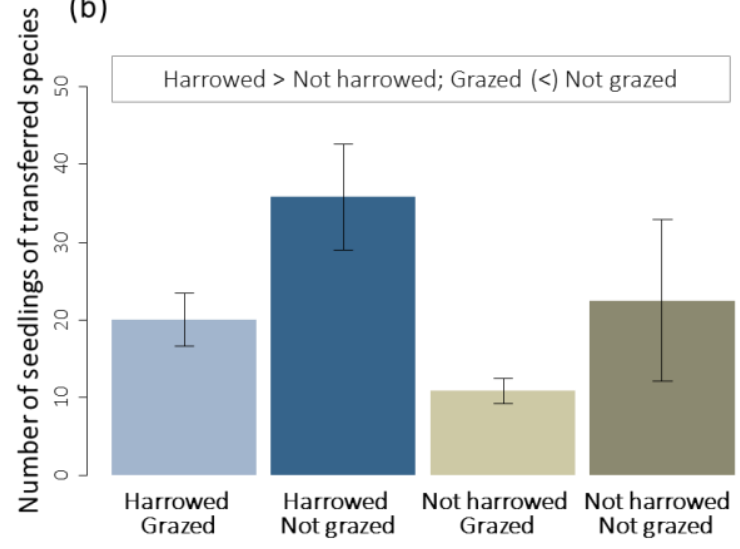

Fig. 1. Number of seedlings per $\mathrm{m}^{2}$ of (a) all species, and of (b) transferred species only, in the four restoration treatments. The direction of main effects is indicated using " $<<$ " $(P<0.01)$, " $<$ " $(P<0.05)$, " $(<)$ " (P<0.1; marginally significant). 


\section{Plant species richness}

3 The treatment effects on overall species richness were not (grazing) or marginally (increase

4 when harrowed) significant (Table 1, Fig. 2a). The species richness of transferred species was

$530 \%$ higher in the harrowed compared to the non-harrowed plots (Fig. 2b). Similarly to the

6 abundance of transferred species, the richness of transferred species was reduced by grazing

7 but the effect was only marginally significant. No significant grazing-by-soil preparation 8 interaction was observed.

9

(a)

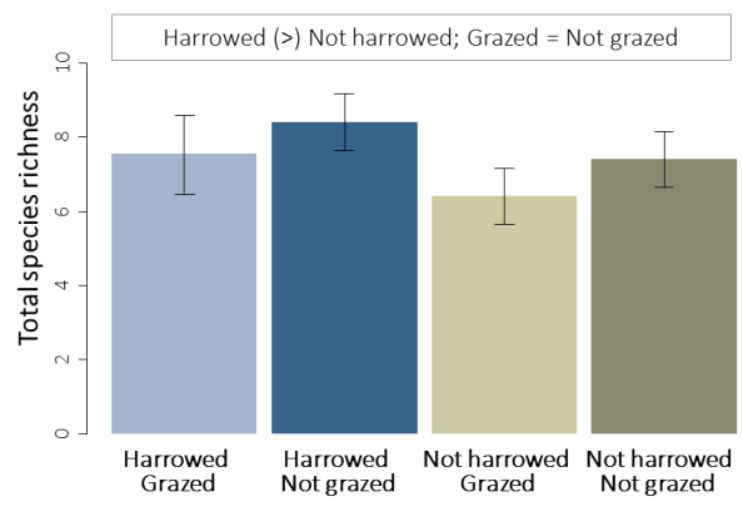

(b)

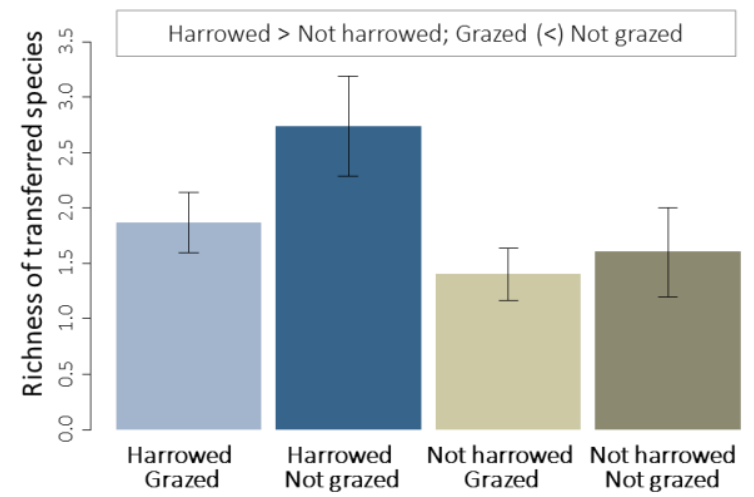

11

Fig. 2. (a) Species richness of seedlings of all species and of (b) transferred species in the four restoration treatments. The direction of main effects is indicated " $<$ " $(P<0.05), "(<)$ " $(P<0.1$; marginally significant) and " $=$ " (not significantly different).

\section{Plant species composition}

The species composition was not clearly separated between treatments resulting in a large overlap of NMDS polygons (Fig. 3). Neither harrowing $(P=0.198)$, nor grazing $(P=0.392)$ nor 
1 the grazing-by-soil preparation interaction $(P=0.461)$ were significant. The plots without soil

2 preparation nor grazing showed higher variation in species composition resulting in a larger

3 polygon. Independent of treatment, semi-dry grassland species such as B. erecta, Saponaria

4 ocymoides L. and Eryngium campestre L. occurred in the upper part of the ordination plot, and

5 ruderal species such as Capsella bursa-pastoris (L.) Medik., Atriplex patula L., Anisantha sterilis

6 (L.) Nevski (former name: Bromus sterilis), Veronica polita Fr. and Polygonum aviculare L. in the

7 lower right part.

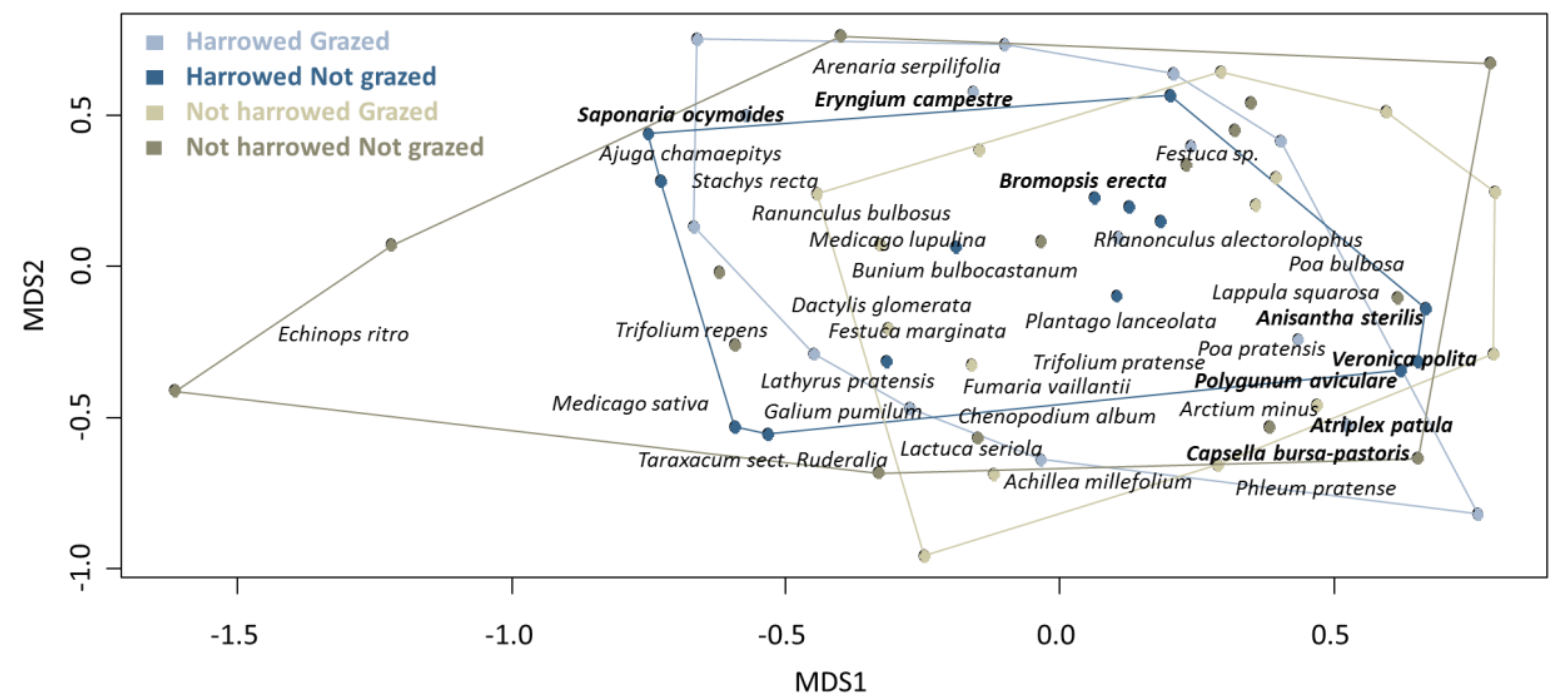

9

10 Fig. 3. Plant species composition in the four restoration treatments using NMDS. Polygons

11 indicate the position of the outmost plots in each treatment (NMDS stress: 0.190).

\section{Seedling survival of two focal species}

14 Seedling survival of $B$. erecta was high in all treatments ( $\geq 75 \%$, Fig. $4 a)$. The main effects of grazing and soil preparation were not significant, but a significant grazing-by-soil preparation 
1 interaction indicated that the grazing effect depended on soil preparation (Table 1). Grazing

2 reduced seedling survival only in non-harrowed plots. With few exceptions, $B$. erecta did not

3 reach the reproductive stage in the first year. The survival rate of $R$. alectorolophus was low

$4 \quad(<45 \%)$ compared to that of B. erecta (Fig. 4 b). Similarly to B. erecta, no significant main effect

5 was found for $R$. alectorolophus but a significant grazing-by-soil preparation interaction

6 explained by a negative grazing effect in non-harrowed plots (Fig. 4b). Most surviving $R$.

7 alectorolophus individuals of the un-grazed, non-harrowed plots were flowering in July, with a

8 significant negative effect of grazing $\left(\chi^{2}=7.348, d f=1, P=0.007\right.$; Appendix S3). Few individuals

9 reached the reproductive stage in the three other treatments types. Similarly to survival, the

significant grazing-by-soil preparation interaction $\left(\chi^{2}=4.100, d f=1, P=0.043\right)$ was explained by a negative grazing effect in non-harrowed plots.
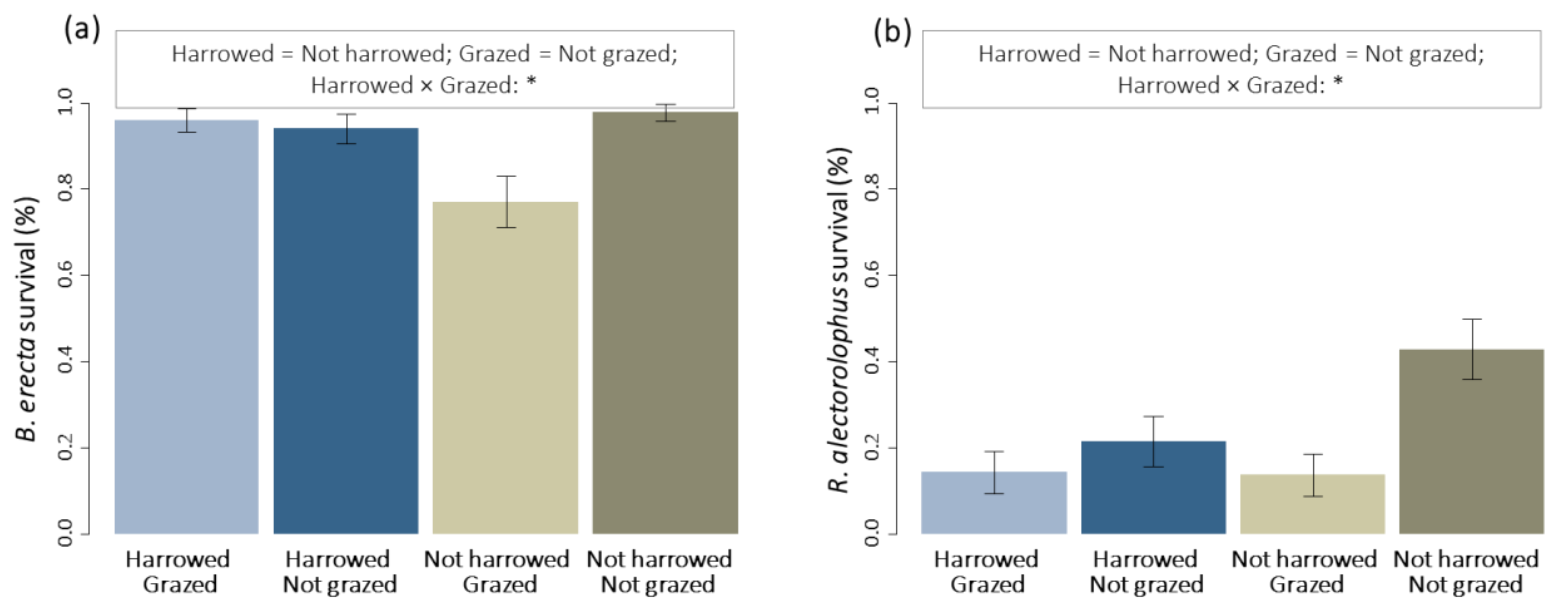

Fig. 4. Final seedling survival of (a) Bromopsis erecta and (b) Rhinanthus alectorolophus. The direction of main effects is indicated using " $<$ " $(\mathrm{P}<0.05)$ and " $=$ " (not significantly different). Significant grazing-by-soil preparation interactions are presented using "*” $(P<0.05)$. 
2 The low field emergence compared with greenhouse germination showed that seedling

3 recruitment may be a bottleneck in ecological restoration of grasslands (Öster et al., 2009). In

4 our study on mountain grasslands, soil preparation largely increased the recruitment of

5 transferred species, whereas competition by spontaneously emerging ruderal species was

6 reduced. Grazing had only a weak negative effect on seedling density. While neither harrowing

7 nor grazing had an effect on focal species survival when applied alone, a significant interaction

8 effect indicated that the grazing effect depended on soil preparation or vice versa. The negative

9 grazing effect was generally stronger in non-harrowed plots. Despite significant grazing and harrowing effects on seedling recruitment and early survival, none of the treatments influenced the first-year plant community composition. germination success and emergence of added seeds because it limits competition of preexisting vegetation (Edwards et al., 2007; Bischoff et al., 2018, Harvolk-Schöning et al., 2020). However, pre-existing vegetation or a mulch layer may also facilitate seedling recruitment (Donath et al., 2007; Scotton et al., 2012). In particular in dry and open habitats, the absence of vegetation cover increases drought stress reducing germination and seedling survival (Callaway and Walker, 1997; Eckstein and Donath, 2005). Our restoration sites in the Upper Durance valley clearly benefitted from previous harrowing indicating that the reduction of competition and improved conditions for germination (Chambers, 2000) prevailed over the reduction of facilitation effects. Similarly, Schmiede et al. (2012) and Harvolk-Schöning et al. 22 (2020) found that the cover of target species was higher following soil disturbance and seed introduction in a floodplain grassland. To our knowledge, our study is the first showing a 
1 simultaneous negative effect of soil preparation on spontaneously emerging species and a

2 positive effect on transferred species. This effect was observed shortly after construction work

3 leading to vegetation degradation and may be even stronger at restoration sites with higher

4 spontaneous vegetation cover (here only $28 \%$ ). The reduced competition by already

5 established species created favourable microsite conditions for the recruitment of transferred

6 species. Soil tillage particularly reduced the abundance of ruderal, competitive species (sensu

7 Grime, 1988), such as Anisantha sterilis (L.) Nevski, Capsella bursa-pastoris (L.) Medik., Atriplex

8 patula L., and Polygonum aviculare L. Without soil disturbance, such competitive early

9 successional species hamper the establishment of the transferred late-successional species

(Donath et al., 2007; Jaunatre et al., 2014). Regardless of competition, harrowing has also been shown to create favourable micro-reliefs improving the adhesion of the transferred seeds to the soil and thus favouring recruitment and establishment (Isselin-Nondedeu et al., 2006). Chambers et al. (2000) showed that seed movements and seedling establishment clearly depended on soil surface structure with holes limiting seed removal and increasing germination. The quantity of removed seeds also depends on the number of transferred seeds and their morphology (size, weight, shape). A better understanding of interactions between soil preparation, seed adhesion to the soil and seed morphology may help to increase the recruitment of transferred species and thus improve the efficiency of restoration measures (Jakobsson and Eriksson, 2000).

Contrary to the soil treatment, the effect of grazing was not selective between transferred species representing the target species of restoration, and non-target species. Grazing had a small but generally negative effect on seedling recruitment. The negative grazing effect was smaller than in other studies of the same geographical region but under Mediterranean climate (Buisson et al., 2015; Vidaller et al., 2019b) in which the transferred 
1 species clearly established better when grazing was excluded. Grazing animals negatively affect seedling recruitment by trampling and later on by biomass removal. Trampling by livestock does not only damage seedlings but also strongly affects the soil by erosion (Farrell and Fehmi, 2018) or destabilization (Tasser et al., 2003), particularly in mountain grassland slopes. On the other hand, trampling may have a positive effect on seedling recruitment of transferred species, since pre-existing vegetation is damaged by bruising, crushing, plant displacement or burial in mud (Bilotta et al., 2007), thus limiting competition with non-target species. Similar to soil preparation, trampling may also create holes reducing seed removal of transferred species (Isselin-Nondedeu et al., 2006). Soil preparation and grazing may thus have a common positive effect: the creation of microsites favourable to recruitment by limiting competition, increasing seed adhesion and water retention (Isselin-Nondedeu et al., 2006; Chambers, 2000). The outcome of the trade-off between microsite creation and seedling damage depends on the productivity of the sites and the timing of grazing. Biomass removal by grazing or mowing is particularly required on highly productive sites where competitive grasses often hamper seedling recruitment and establishment (Schmiede et al., 2012; Kladivova and Münzbergova, 2016). Nutrient-poor sites rather need protection of seedlings against grazing than biomass removal since competition is much lower (Kirmer et al., 2012; Scotton et al., 2012; Vidaller et al., 2019a, 2019b). The marginally significant negative grazing effect in our study may thus be explained by the intermediate productivity level of our restoration sites. Post-pasture sowing has been cited as a method to optimise timing, because it allows seedlings to develop before the next grazing, reducing trampling and herbivory at the most vulnerable stage (Eichberg and Donath, 2018). Our study sites were first grazed before seedling emergence, 2-3 weeks after 23 brush material transfer, and the following grazing period occurred seven months later. Thus, 
1 vegetation, but the second grazing period may have negatively affected young seedlings that

2 predominantly emerged in spring, finally resulting in a slightly negative effect of grazing. The

3 vegetation period usually starts after snow melt in March resulting in a low probability to attain

4 maturity before the June grazing period. The timing of grazing needs to be taken into account

5 to limit the damage on seedlings, particularly if grazing exclusion is not possible. Livestock type may influence grazing effects (Tóth et al., 2016). In our study, we focused on an overall grazing effect including sheep and cattle, and the grazer species effect was pooled with experimental site. It may be interesting for future studies to distinguish effects of cattle and sheep grazing. The analysis of seedling survival of two focal species confirmed these conclusions. The grazing effect was small and limited to plots without soil preparation. The vegetation of these non-harrowed plots was denser and thus more attractive for grazers explaining the higher grazing effect. Grazing livestock prefers dense vegetation with higher food resource over sparse vegetation resulting in a higher biomass removal (Török et al., 2014; Meuret and Provenza 2015). B. erecta showed a generally high survival rate after three months suggesting that the species, characteristic of semi-dry soils and semi-natural sites, is very well adapted to the pedoclimatic conditions of our study zone and resistant to grazing (Calaciura and Spinelli, 2008). Rhinanthus alectorolophus showed, however, a much lower survival since the abundance of potential host plants was low during the first year of restoration. The species is a hemi-parasite and its performance depends on the availability and performance of host plants (Matthies and Egli, 1999; Bullock et al., 2003). It cannot establish under low vegetation cover and its population may go locally extinct as it is an annual species whose year-to-year survival relies on the production of seeds and seedling recruitment (Coulson et al., 2001; Bullock et al., 2003). Whereas the grazing effect on the survival of $R$. alectorolphus was not significant, the effect on 
1 flower production was negative. The result suggests that the species may survive grazing, but

2 grazing damage prevent species from flowering. The differential effects of soil preparation and grazing on spontaneous and transferred species did not result in a change in first-year plant species composition. The abundance of spontaneously emerging species was between six and ten times higher than that of transferred species, explaining that the observed significant soil treatment effect on transferred species was not yet visible at community level. The soil of disturbed sites generally contains high numbers of seeds of annuals and/or ruderal species (Bischoff, 2002; Donath et al., 2007). These species often dominate the vegetation of early successional stages before being replaced by typical grassland species that are usually perennials developing later in the succession (Kiehl et al., 2010; Valkó et al., 2016; Kiss et al., 2020). The first year after the restoration of Eastern European grasslands, Lengyel et al. (2012) observed that annual weeds were dominant, but the cover of those weeds decreased dramatically after the third year due to the growth of perennial grasses. The authors observed an increase in the cover of target species from the first to the fourth year of restoration. A similar low initial restoration treatment effect due to initial low establishment of transferred target species and a subsequent high long-term restoration success (eight years) is known for riparian mesophilous grasslands (Auestad et al., 2016; Bischoff et al., 2018). Monitoring the plant community over several years will be necessary in order to evaluate whether the observed initial differences in seedling recruitment and early survival significantly influence plant species composition and restoration success in the long run.

\section{CONCLUSION}


1 Most species of the donor site were found at the restoration sites indicating that the applied

2 brush harvesting technique was appropriate and allowed testing soil preparation and grazing

3 effects. Similarly to studies in mesophilous grasslands (Edwards et al., 2007, Bischoff et al.,

4 2018), soil preparation had a clearly positive effect on the seedling recruitment. The reduction

5 in overall seedling density dominated by spontaneously emerging species demonstrated that

6 the reduction in competition was the principal mechanism explaining the positive effect of

7 previous soil tillage by harrowing on the recruitment of transferred species (Edwards et al.,

8 2007; Schmiede et al., 2012). We thus recommend soil preparation before seed-based

9 ecological restoration even in semi-dry grasslands to improve seedling recruitment of

transferred target species. Our study did not confirm a strong negative effect of grazing on seedling recruitment found by several other authors (Scotton et al., 2012; Vidaller et al., 2019b). The marginally significant negative effect of extensive grazing may be tolerated if farmers are reluctant in putting up fences as in our study area. Further research is needed on the timing of sowing relative to grazing periods, in order to benefit from positive grazing effects by reduction of competition while avoiding seedling damage.

We would like to thank Daniel Pavon for his valuable help in plant species identification. We thank Alice Dupré-la-Tour and Sophie Duhautois for assistance in logistics and project coordination. We are grateful to Jean-François Alignan, Antoine Beltrame, Sarah Kalkas, Jeanne Pénaud, Tiago Toma and Christel Vidaller for their help in the field and for seed counting. 


\section{REFERENCES}

Allington, G. R. H., \& Valone, T. J. (2011). Long-Term Livestock Exclusion in an Arid Grassland Alters Vegetation and Soil. Rangeland Ecology \& Management, 64(4), 424-428. https://doi.org/10.2111/REM-D-10-00098.1

Auestad, I., Rydgren, K., \& Austad, I. (2016). Near-natural methods promote restoration of species-rich grassland vegetation - revisiting a road verge trial after 9 years. Restoration Ecology, 24, 381-389. https://doi.org/10.1111/rec.12319

Bakker, E.S. (2003). Herbivores as mediators of their environment: the impact of large and small species on vegetation dynamics. PhD-thesis. Wageningen University, Wageningen, The Netherlands. ISBN 90-5808-878-2; pp. 1-184.

Bilotta, G. S., Brazier, R. E., \& Haygarth, P. M. (2007). The Impacts of Grazing Animals on the Quality of Soils, Vegetation, and Surface Waters in Intensively Managed Grasslands. Advances in Agronomy 94, 237-280. Academic Press. https://doi.org/10.1016/S00652113(06)94006-1

Bischoff, A. (2002). Dispersal and establishment of floodplain grassland species as limiting factors in restoration. Biological Conservation, 104(1), 25-33. https://doi.org/10.1016/S0006-3207(01)00151-3

Bischoff, A., Hoboy, S., Winter, N., \& Warthemann, G. (2018). Hay and seed transfer to reestablish rare grassland species and communities: How important are date and soil preparation? Biological Conservation, 221, 182-189. https://doi.org/10.1016/j.biocon.2018.02.033

Bischoff, A., Warthemann, G., \& Klotz, S. (2009). Succession of floodplain grasslands following reduction in land use intensity: the importance of environmental conditions, 
management and dispersal. Journal of Applied Ecology, 46(1), 241-249. https://doi.org/10.1111/j.1365-2664.2008.01581.x

Bissels, S., Donath, T. W., Hölzel, N., \& Otte, A. (2006). Effects of different mowing regimes on seedling recruitment in alluvial grasslands. Basic and Applied Ecology, 7(5), 433-442. https://doi.org/10.1016/j.baae.2005.10.002

Buisson, E., Corcket, E., \& Dutoit, T. (2015). Limiting processes for perennial plant reintroduction to restore dry grasslands. Restoration Ecology, 23(6), 947-954. https://doi.org/10.1111/rec.12255

Buisson, E., Jaunatre, R., Römermann, C., Bulot, A., \& Dutoit, T. (2018). Species transfer via topsoil translocation: lessons from two large Mediterranean restoration projects. Restoration Ecology, 26(S2), S179-S188. https://doi.org/10.1111/rec.12682

Bullock, J. M., Moy, I. L., Coulson, S. J., \& Clarke, R. T. (2003). Habitat-specific dispersal: environmental effects on the mechanisms and patterns of seed movement in a grassland herb Rhinanthus minor. Ecography, 26(5), 692-704. https://doi.org/10.1034/j.1600-0587.2003.03525.x

Bullock, J. M., \& Pywell, R. F. (2005). Rhinanthus: a tool for restoring diverse grassland? Folia Geobotanica, 40(2), 273-288. https://doi.org/10.1007/BF02803240

Calaciura, B., \& Spinelli, O. (2008). Management of Natura 2000 habitats. 6210 Semi-natural dry grasslands and scrubland facies on calcareous substrates (Festuco-Brometalia) (*important orchid sites). Technical Report 2008 12/24, European Commission.

Callaway, R. M., \& Walker, L. R. (1997). Competition and Facilitation: A Synthetic Approach to Interactions in Plant Communities. Ecology, 78(7), 1958-1965. https://doi.org/10.1890/0012-9658(1997)078[1958:CAFASA]2.0.CO;2 
1 Chambers, J. C. (2000). Seed movements and seedling fates in disturbed sagebrush steppe ecosystems: implications for restoration. Ecological Applications, 10(5), 1400-1413. https://doi.org/10.1890/1051-0761(2000)010[1400:SMASFI]2.0.CO;2

Coulson, S. J., Bullock, J. M., Stevenson, M. J., \& Pywell, R. F. (2001). Colonization of grassland by sown species: dispersal versus microsite limitation in responses to management. Journal of Applied Ecology, 38(1), 204-216. https://doi.org/10.1046/j.13652664.2001.00585.x

Di H. J., \& K. C. Cameron. (2002). Nitrate Leaching in Temperate Agroecosystems: Sources, Factors and Mitigating Strategies. Nutrient Cycling in Agroecosystems, 64(3), 237-56. https://doi.org/10.1023/A:1021471531188

Donath, T. W., Bissels, S., Hölzel, N., \& Otte, A. (2007). Large scale application of diaspore transfer with plant material in restoration practice - Impact of seed and microsite limitation. Biological Conservation, 138(1), 224-234. https://doi.org/10.1016/j.biocon.2007.04.020

Dupré, C., \& Diekmann, M. (2001). Differences in species richness and life-history traits between grazed and abandoned grasslands in southern Sweden. Ecography, 24(3), 275-286. https://doi.org/10.1111/j.1600-0587.2001.tb00200.x

Durbecq, A., Jaunatre, R., Buisson, E., Cluchier, A., \& Bischoff, A. (2020). Identifying reference communities in ecological restoration: the use of environmental conditions driving vegetation composition. Restoration Ecology, 28(6), 1445-53. https://doi.org/10.1111/rec.13232

Eckstein, R. L., \& Donath, T. W. (2005). Interactions between litter and water availability affect seedling emergence in four familial pairs of floodplain species. Journal of Ecology, 93(4), 807-816. https://doi.org/10.1111/j.1365-2745.2005.01015.x 
Edwards, A. R., Mortimer, S. R., Lawson, C. S., Westbury, D. B., Harris, S. J., Woodcock, B. A., \& Brown, V. K. (2007). Hay strewing, brush harvesting of seed and soil disturbance as tools for the enhancement of botanical diversity in grasslands. Biological Conservation, 134(3), 372-382. https://doi.org/10.1016/j.biocon.2006.08.025

Eichberg, C., \& Donath, T. W. (2018). Sheep trampling on surface-lying seeds improves seedling recruitment in open sand ecosystems. Restoration Ecology, 26(S2), S211-S219. https://doi.org/10.1111/rec.12650

Ellenberg, H. (1996). Vegetation Mitteleuropas mit den Alpen in ökologischer Sicht. 4. Aufl., Verlag Eugen Ulmer, Stuttgart.

Farrell, H. L., \& Fehmi, J. S. (2018). Seeding alters plant community trajectory: Impacts of seeding, grazing and trampling on semi-arid re-vegetation. Applied Vegetation Science, 21(2), 240-249. https://doi.org/10.1111/avsc.12340

Frances, A. L., Adams, C. R., \& Norcini, J. G. (2010). Importance of Seed and Microsite Limitation: Native Wildflower Establishment in Non-native Pasture. Restoration Ecology, 18(6), 944-953. https://doi.org/10.1111/j.1526-100X.2009.00629.x

Grman, E., Bassett, T., Zirbel, C. R., \& Brudvig, L. A. (2015). Dispersal and establishment filters influence the assembly of restored prairie plant communities. Restoration Ecology, 23(6), 892-899. https://doi.org/10.1111/rec.12271

Grubb, P. J. (1977). The Maintenance of Species-Richness in Plant Communities: The Importance of the Regeneration Niche. Biological Reviews, 52(1), 107-145. https://doi.org/10.1111/j.1469-185X.1977.tb01347.x

Harvolk-Schöning, S., Michalska-Hejduk, D., Harnisch, M., Otte, A., \& Donath, T. W. (2020). Floodplain meadow restoration revisited: Long-term success of large scale application 
of diaspore transfer with plant material in restoration practice. Biological Conservation, 241, 108322. https://doi.org/10.1016/j.biocon.2019.108322

Heer, N., Klimmek, F., Zwahlen, C., Fischer, M., Hölzel, N., Klaus, V. H., Kleinebecker, T., Prati, D., \& Boch, S. (2018). Hemiparasite-density effects on grassland plant diversity, composition and biomass. Perspectives in Plant Ecology, Evolution and Systematics 32, 22-29. https://doi.org/10.1016/j.ppees.2018.01.004

Hejcman, M., Hejcmanová, P., Pavlů, V., \& Beneš, J. (2013). Origin and history of grasslands in Central Europe - a review. Grass and Forage Science, 68(3), 345-363. https://doi.org/10.1111/gfs.12066

Hölzel, N., \& Otte, A. (2003). Restoration of a species-rich flood meadow by topsoil removal and diaspore transfer with plant material. Applied Vegetation Science, 6(2), 131-140. https://doi.org/10.1111/j.1654-109X.2003.tb00573.x

Holland, J. M. (2004). The environmental consequences of adopting conservation tillage in Europe: reviewing the evidence. Agriculture, Ecosystems and Environment, 103, 1-25.

Isselin-Nondedeu, F., Rey, F., \& Bédécarrats, A. (2006). Contributions of vegetation cover and cattle hoof prints towards seed runoff control on ski pistes. Ecological Engineering, 27(3), 193-201. https://doi.org/10.1016/j.ecoleng.2006.02.006

Jakobsson, A., \& Eriksson, O. (2000). A comparative study of seed number, seed size, seedling size and recruitment in grassland plants. Oikos, 88(3), 494-502. https://doi.org/10.1034/j.1600-0706.2000.880304.x

Jaunatre, R., Buisson, E., \& Dutoit, T. (2014). Topsoil removal improves various restoration treatments of a Mediterranean steppe (La Crau, southeast France). Applied Vegetation Science, 17(2), 236-245. https://doi.org/10.1111/avsc.12063 
1 Kiehl, K., Kirmer, A., Donath, T. W., Rasran, L., \& Hölzel, N. (2010). Species introduction in restoration projects - Evaluation of different techniques for the establishment of seminatural grasslands in Central and Northwestern Europe. Basic and Applied Ecology, 11(4), 285-299. https://doi.org/10.1016/j.baae.2009.12.004

Kirmer, A., Baasch, A., \& Tischew, S. (2012). Sowing of low and high diversity seed mixtures in ecological restoration of surface mined-land. Applied Vegetation Science, 15(2), 198207. https://doi.org/10.1111/j.1654-109X.2011.01156.x

Kiss, R., Deák, B., Tóthmérész, B., Miglécz, T., Tóth, K., Török, P., et al. (2020). Establishment Gaps in Species-Poor Grasslands: Artificial Biodiversity Hotspots to Support the Colonization of Target Species. Restoration Ecology n/a(n/a). http://doi.org/10.1111/rec.13135

Kladivová, A., \& Münzbergová, Z. (2016). Interacting effects of grazing and habitat conditions on seedling recruitment and establishment. Journal of Vegetation Science, 27(4), 834843. https://doi.org/10.1111/jvs.12395

Klaus, V. H., Schäfer, D., Kleinebecker, T., Fischer, M., Prati, D., \& Hölzel, N. (2017). Enriching Plant Diversity in Grasslands by Large-Scale Experimental Sward Disturbance and Seed Addition along Gradients of Land-Use Intensity. Journal of Plant Ecology, 10(4), 581-91. https://doi: 10.1093/jpe/rtw062

Koch, E.-M., Spiegelberger, T., Barrel, A., Bassignana, M., \& Curtaz, A. (2015). Les semences locales dans la restauration écologique en montagne. Production et utilisation de mélanges pour la préservation. Institut Agricole Régional, Rég. La Rochère 1/A, I-11100 Aoste. 
1 Kupferschmid, A. D., Stampfli, A., \& Newbery, D. M. (2000). Dispersal and microsite limitation in an abandoned calcareous grassland of the southern prealps. Folia Geobotanica, 35(2), 125-141. https://doi.org/10.1007/BF02803092

Lengyel, S., Varga, K., Kosztyi, B., Lontay, L., Déri, E., Török, P., \& Tóthmérész, B. (2012). Grassland restoration to conserve landscape-level biodiversity: a synthesis of early results from a large-scale project. Applied Vegetation Science, 15(2), 264-276. https://doi.org/10.1111/j.1654-109x.2011.01179.x

Long, Q., Foster, B. L., \& Kindscher, K. (2014). Seed and microsite limitations mediate stochastic recruitment in a low-diversity prairie restoration. Plant Ecology, 215(11), 1287-1298. https://doi.org/10.1007/s11258-014-0387-y

Matthies, D., \& Egli, P. (1999). Response of a root hemiparasite to elevated CO2 depends on host type and soil nutrients. Oecologia, 120: 156-161.

Meuret, M., \& Provenza, F. (2015). When Art and Science Meet: Integrating Knowledge of French Herders with Science of Foraging Behavior. Rangeland Ecology \& Management, 68, 1-17. http://doi.org/10.1016/j.rama.2014.12.007.

Muller, I., Mesléard, F., \& Buisson, E. (2014). Effect of topsoil removal and plant material transfer on vegetation development in created Mediterranean meso-xeric grasslands. Applied Vegetation Science, 17(2), 246-261. https://doi.org/10.1111/avsc.12059

Münzbergová, Z., \& Herben, T. (2005). Seed, dispersal, microsite, habitat and recruitment limitation: identification of terms and concepts in studies of limitations. Oecologia, 145(1), 1-8. https://doi.org/10.1007/s00442-005-0052-1

Myers, J. A., \& Harms, K. E. (2009). Seed arrival, ecological filters, and plant species richness: a meta-analysis. Ecology Letters, 12(11), 1250-1260. https://doi.org/10.1111/j.14610248.2009.01373.x 
1 Oksanen, J., Blanchet, F.G., Friendly, M., Kindt, R., Legendre, P., McGlinn, D. et al. (2019). Vegan: Community Ecology Package. R package version 2.5-4. Available at https://cran.rproject.org/web/packages/vegan/index.html

Öster, M., Ask, K., Cousins, S. A. O., \& Eriksson, O. (2009). Dispersal and establishment limitation reduces the potential for successful restoration of semi-natural grassland communities on former arable fields. Journal of Applied Ecology, 46(6), 1266-1274. https://doi.org/10.1111/j.1365-2664.2009.01721.x

Poschlod, P., \& Biewer, H. (2005). Diaspore and gap availability are limiting species richness in wet meadows. Folia Geobotanica, 4O(1), 13-34. https://doi.org/10.1007/BF02803041

Pykälä, J. (2003). Effects of restoration with cattle grazing on plant species composition and richness of semi-natural grasslands. Biodiversity \& Conservation, 12(11), 2211-2226. https://doi.org/10.1023/A:1024558617080

Pywell, R. F., Bullock, J. M., Hopkins, A., Walker, K. J., Sparks, T. H., Burke, M. J. W., \& Peel, S. (2002). Restoration of species-rich grassland on arable land: assessing the limiting processes using a multi-site experiment. Journal of Applied Ecology, 39(2), 294-309. https://doi.org/10.1046/j.1365-2664.2002.00718.x

R Core Team (2019). R: a language and environment for statistical computing. R Foundation for Statistical Computing, Vienna, Austria https://www.Rproject.org/

Rother, D. C., Jordano, P., Rodrigues, R. R., \& Pizo, M. A. (2013). Demographic bottlenecks in tropical plant regeneration: A comparative analysis of causal influences. Perspectives in Plant Ecology, Evolution and Systematics, 15(2), 86-96. https://doi.org/10.1016/j.ppees.2012.12.004

Saatkamp, A., Henry, F., \& Dutoit, T. (2018). Vegetation and soil seed bank in a 23-year grazing exclusion chronosequence in a Mediterranean dry grassland. Plant Biosystems - An 
International Journal Dealing with All Aspects of Plant Biology, 152(5), 1020-1030. https://doi.org/10.1080/11263504.2017.1407375

Sandner, T. M., \& Matthies, D. (2018). Multiple choice: hemiparasite performance in multispecies mixtures. Oikos, 127(9), 1291-1303. https://doi.org/10.1111/oik.05148

Schmiede, R., Otte, A., \& Donath, T. W. (2012). Enhancing plant biodiversity in species-poor grassland through plant material transfer - the impact of sward disturbance. Applied Vegetation Science, 15(2), 290-298. https://doi.org/10.1111/j.1654109X.2011.01168.x

Scotton, M., Kirmer, A., \& Krautzer, B. (2012). Practical handbook for seed harvest and ecological restoration of species-rich grasslands. Padova, Italy: Cooperativa Libraria $\begin{array}{lll}\text { Editrice } & \text { Universitá } & \text { di }\end{array}$ https://www.cabdirect.org/cabdirect/abstract/20123217113

Shaw, N., Barak, R. S., Campbell, R. E., Kirmer, A., Pedrini, S., Dixon, K., \& Frischie, S. (2020). Seed use in the field: Delivering seeds for restoration success. Restoration Ecology, n/a(n/a). https://doi.org/10.1111/rec.13210

Tasser, E., Mader, M., \& Tappeiner, U. (2003). Effects of land use in alpine grasslands on the probability of landslides. Basic and Applied Ecology, 4(3), 271-280. https://doi.org/10.1078/1439-1791-00153

Tilman, D. (1997). Community Invasibility, Recruitment Limitation, and Grassland Biodiversity. Ecology, $\quad$ 78(1), $\quad$ 81-92. $\quad$ https://doi.org/10.1890/00129658(1997)078[0081:CIRLAG]2.0.CO;2

Tison, J.-M., Jauzein, P., \& Michaud, H. (2014). Flore de la France méditerranéenne continentale. Naturalia Publications. 
1 Török, P., Miglécz, T., Valkó, O., Kelemen, A., Tóth, K., Lengyel, S., \& Tóthmérész, B. (2012). Fast restoration of grassland vegetation by a combination of seed mixture sowing and lowdiversity hay transfer. Ecological Engineering, 44, 133-138. https://doi.org/10.1016/j.ecoleng.2012.03.010

Török, P., Valkó, O., Deák, B., Kelemen, A., \& Tóthmérész, B. (2014). Traditional Cattle Grazing in a Mosaic Alkali Landscape: Effects on Grassland Biodiversity along a Moisture Gradient. PLoS ONE, 9(5): e97095. https://doi.org/10.1371/journal.pone.0097095

Tóth, E., Balázs, D., Valkó, O., Kelemen, A., Miglécz, T., Tóthmérész, B., \& Török, P. (2016). Livestock Type is More Crucial Than Grazing Intensity: Traditional Cattle and Sheep Grazing in Short-Grass Steppes. Land Degradation \& Development. 29(2). 231-239. $10.1002 / \operatorname{ldr} .2514$

Turnbull, L. A., Crawley, M. J., \& Rees, M. (2000). Are plant populations seed-limited? A review of seed sowing experiments. Oikos, 88(2), 225-238. https://doi.org/10.1034/j.16000706.2000.880201.x

Valkó, O., Deák, B., Török, P., Kirmer, A., Tischew, S., Kelemen, A., et al. (2016). High-diversity sowing in establishment gaps: a promising new tool for enhancing grassland biodiversity. Tuexenia 36, 359-78. http://dx.doi.org/10.14471/2016.36.020

Vidaller, C., Dutoit, T., Ramone, H., \& Bischoff, A. (2019a). Fire increases the reproduction of the dominant grass Brachypodium retusum and Mediterranean steppe diversity in a combined burning and grazing experiment. Applied Vegetation Science, 22(1), 127-137. https://doi.org/10.1111/avsc.12418

Vidaller, C., Dutoit, T., Ramone, H., \& Bischoff, A. (2019b). Factors limiting early establishment of the Mediterranean grassland species Brachypodium retusum at disturbed sites. Basic and Applied Ecology, 37, 10-19. https://doi.org/10.1016/j.baae.2019.04.003 
1 Zeiter, M., Stampfli, A., \& Newbery, D. M. (2006). Recruitment Limitation Constrains Local

2

3

4

5

6

7

8 SUPPORTING INFORMATION

9 Additional supporting information may be found online in the Supporting Information section at 10

Appendix S2. Seedling emergence ex-situ and in-situ.

13

Appendix S3. Reproductive individuals of Rhinanthus alectorolophus. 